\title{
ЗАГАЛЬНОДИДАКТИЧНА МОДЕЛЬ НАВЧАЛЬНОГО ПРЕДМЕТА ЯК ДИДАКТИЧНА ОСНОВА ДОБОРУ І КОНСТРУЮВАННЯ ТЕОРЕТИЧНОГО КОМПОНЕНТА ЗМІСТУ ФІЗКУЛЬТУРНОÏ ОСВІТИ
}

\author{
Кандидат педагогічних наук, доцент Ю.В. Васьков
}

\section{Харківський ОІППОМ}

Однією з важливих i, на жаль, невирішених проблем дидактики є добір і конструювання змісту загальної середньої освіти, який відповідав би попиту і вимогам сучасного виробництва, відігравав певну роль в інтелектуальному і фізичному становленні підростаючого покоління, формуванні різнобічно розвинутої особистості.

3 метою забезпечення системного підходу до добору і конструювання змісту загальної середньої освіти в сучасній педагогічній науці виділяється три основних рівні формування змісту:

1. Рівень загального теоретичного уявлення. На цьому рівні зміст освіти фіксується у вигляді узагальненого системного уявлення про склад (елементи), структуру (зв'язок між елементами) і суспільні функції соціального досвіду, що передасться в надбання підростаючому поколінню в педагогічній інтерпретації.

2. Рівень навчального предмета. На цьому рівні розгортаються уявлення про певні частини змісту освіти, які несуть специфічні функції в загальній середній освіті. Специфікою цих функцій є особливі для кожного навчального предмета, але співвідносні з загальним теоретичним уявленням склад і структура змісту.

3. Рівень навчального матеріалу. На цьому рівні подані конкретні, доступні учням, фіксовані в підручниках, навчальних посібниках, програмах складові елементи змісту освіти (знання, уміння, навички та ін.), що входять у курс навчання певного навчального предмета.

Зміст фізкультурної освіти є певною частиною загальної середньої освіти і складається, за І.Я. Лернером, з чотирьох основних компонентів: знання, способи діяльності, досвід творчого застосування знань і способів діяльності, досвід емоційноціннісного ставлення до засвоюваного змісту освіти.

У відповідності з концепцією В.В. Краєвського [8], зміст освіти отримує певну конкретизацію на рівні навчального предмета. Цілком ясно, що логіка добору і конструювання змісту освіти на цьому рівні залежить від розуміння змісту поняття «Навчальний предмет».

У сучасній дидактиці $[1,5,6,7,8]$ під навчальним предметом розуміють педагогічно адаптований зміст основ будь-якої галузі діяльності. Кожна з галузей може поділятися і поділяється на навчальні предмети у відповідності до членування самої галузі і завдань навчання. Тобто склад навчального предмета обумовлюється завданням за- гальної освіти. Будь-який шкільний навчальний предмет вміщує всі елементи соціального досвіду, що віддзеркалені в предметному змісті однієї чи ряду галузей діяльності - тобто знання, способи діяльності, досвід творчої і емоційно-ціннісної діяльності.

Навчальний предмет - один 3 головних засобів реалізації змісту освіти, що поєднує в нерозривне ціле зміст, який підлягає засвоєнню, із засобами засвоєння його учнями, а також сприяє розвитку і вихованню дітей.

Традиційно навчальні предмети поділяються на два великі цикли (групи): цикл природничонаукових і цикл гуманітарних дисциплін. Такий поділ навчальних предметів об'єктивно відповідає поділу наук за об'єктом вивчення: науки про природу і науки про людину.

Останнім часом все більше визнання отримує теоретична концепція навчального предмета, розроблена І.К. Журавльовим і Л.Я. Зоріною [2, 3, 4], які об'єднують навчальні предмети за іншою основою - провідною метою предмета, в навчальному плані. Саме провідна мета виявляє найбільш загальне в конструюванні змісту і в організаціі процесу навчання. Кожен предмет має декілька цілей, але серед них є провідна, заради якої його і введено до навчального плану. Ця головна ціль навчального предмета зумовлює його провідний компонент, за допомогою якого можлива реалізація всіх інших завдань. Відповідно до провідного компонента всі навчальні предмети поділяються на три групи:

I. Навчальні предмети з провідним компонентом «наукові знання», або «основи наук» (фізика, хімія, біологія, астрономія, географія та ін.).

II. Навчальні предмети 3 провідним компонентом «способи діяльності» (іноземна мова, креслення, фізична культура, комплекс дисциплін трудового навчання, інформатика).

III. Навчальні предмети 3 провідним компонентом «художня освіта і естетичне виховання», або «естетичне бачення світу» (образотворче мистецтво, музика).

Виходячи з зазначеної типології, автори побудували і теоретично обгрунтували загальнодидактичну модель навчального предмета (рис. 1).

Дидактична модель навчального предмета - це певна цілісність, що має два блоки: основний, до якого входить в першу чергу той зміст, заради якого навчальний предмет введений у навчальний план, i блок засобів, або процесуальний блок, що забез- 
печує засвоєння знань, формування різних умінь і навичок, розвиток і виховання (Зоріна Л.Я., 1989).

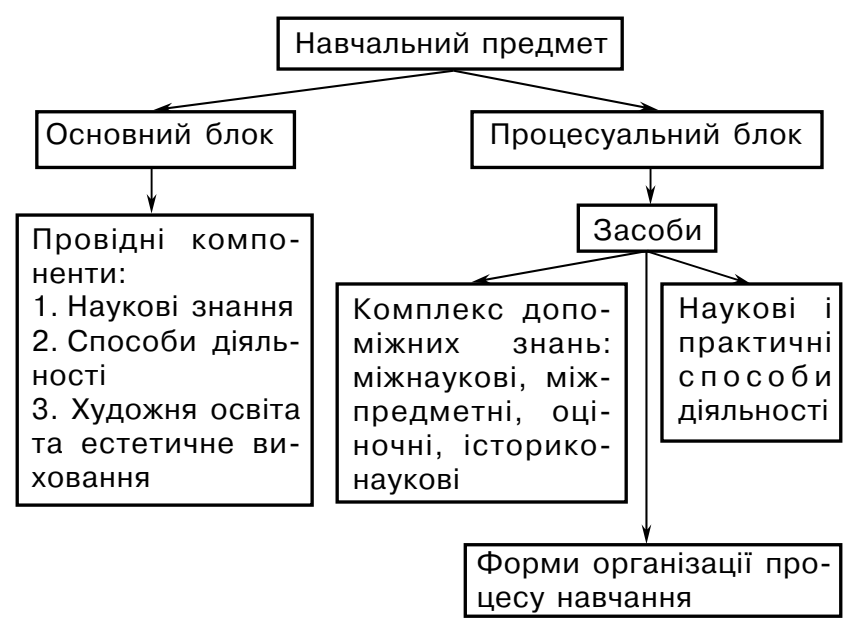

Рис. 1. Дидактична модель навчального предмета

Розроблену дидактичну модель навчального предмета можна розкрити і в іншому вигляді:

\begin{tabular}{|c|c|c|c|}
\hline Основний блок & \multicolumn{3}{|c|}{ Процесуальний блок } \\
\hline $\begin{array}{l}\text { Провідні компо- } \\
\text { ненти: } \\
\text { 1. Наукові знання } \\
\text { 2. Способи діяль- } \\
\text { ності } \\
\text { 3. Художня освіта } \\
\text { і естетичне ви- } \\
\text { ховання }\end{array}$ & \begin{tabular}{|l} 
Комплекс \\
допоміжних \\
знань: \\
- міжпред- \\
$\quad$ метні; \\
- міжнауко- \\
$\quad$ ві; \\
- історико- \\
$\quad$ наукові; \\
- оцінюва- \\
$\quad$ льні
\end{tabular} & $\begin{array}{l}\text { Наукові і } \\
\text { практичні } \\
\text { способи } \\
\text { діяльності }\end{array}$ & $\begin{array}{l}\text { Форми } \\
\text { орга- } \\
\text { нізації } \\
\text { процесу } \\
\text { навчання }\end{array}$ \\
\hline
\end{tabular}

У відповідності до загальнодидактичної моделі навчального предмета, дидактична модель навчального предмета «Фізична культура», провідним компонентом якого є «способи діяльності», має такий вигляд:

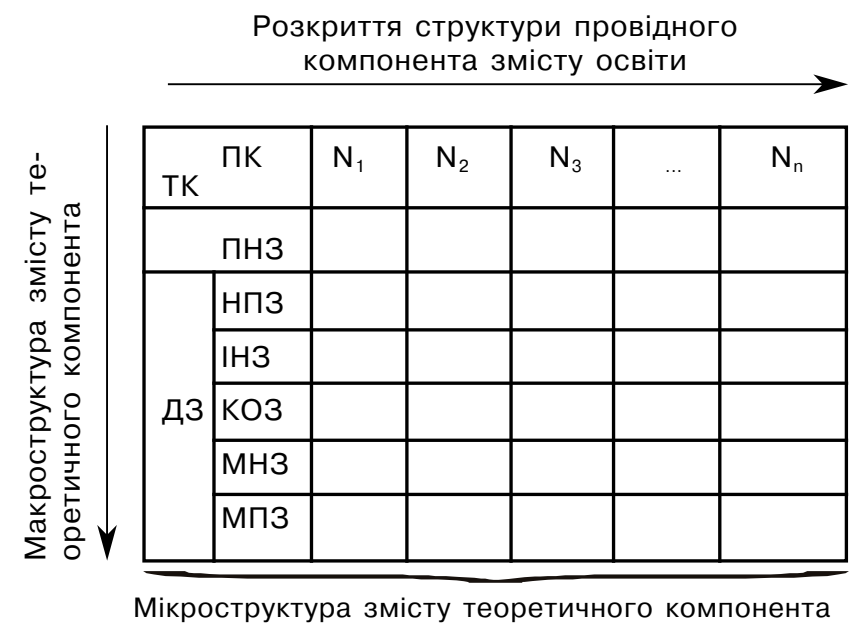

Рис. 2. Процесуальна матриця добору і конструювання теоретичного компонента, змісту фізкультурної освіти

Де: ПК - провідний компонент змісту фізкультурної освіти (способи діяльності);

N - елементи структури провідного компонента;

TK - теоретичний компонент змісту фізкультурної освіти;

ПНЗ - предметно-наукові знання;

Д3 - допоміжні знання;

НПЗ - нормативно-профілактичні знання;

IH3 - історико-наукові знання;

КО3 - контрольно-оціночні знання;

МН3 - міжнаукові знання (з логіки, психології, педагогіки, анатомії, фізіології, гігієни та ін.);

МПЗ - міжпредметні знання.

Як видно з наведеної матриці, по горизонталі розкривається структура провідного компонента змісту фізкультурної освіти - об'єктивуються елементи способу діяльності.

По вертикалі зверху вниз розкриваються основні змістові блоки теоретичного компонента його макроструктура: ПН3, НП3, IH3, КО3, МН3, МПЗ.

\begin{tabular}{|l|l|l|l|l|}
\hline Тип навчального предмета & \multicolumn{1}{|c|}{ Основний блок } & \multicolumn{3}{|c|}{ Процесуальний блок } \\
\hline $\begin{array}{l}\text { 3 провідним компонентом, } \\
\text { «способи діяльності» }\end{array}$ & Способи діяльності & $\begin{array}{l}\text { I. Комплекс допоміжних } \\
\text { знань: }\end{array}$ & $\begin{array}{l}\text { II. Допоміжні } \\
\text { способи } \\
\text { діяльності }\end{array}$ & $\begin{array}{l}\text { III. Форми } \\
\text { організації } \\
\text { навчання }\end{array}$ \\
& & $\begin{array}{l}\text { а) власні допоміжні знання; } \\
\text { сукупність предметно- } \\
\text { наукових знань }\end{array}$ & & \\
\hline
\end{tabular}

На основі структурних компонентів наведеної дидактичної моделі навчального предмета «Фізична культура» нами була побудована матриця як інструментальна основа добору і конструювання теоретичного компонента змісту фізкультурної освіти (рис. 3).

Логіка побудови матриці передбачає рух думки від структури провідного компонента (структури способу діяльності) до структури змісту теоретичного компонента.
Мікроструктуру теоретичного компонента розкривають у полі матриці по горизонталях у відповідності до кожного змістового блоку.

Алгоритм добору і конструювання теоретичного компонента змісту фізкультурної освіти на основі розробленої нами матриці передбачають певну процедуру:

1. Визначити спосіб діяльності на основі провідного дидактичного завдання засвоєння конкретної теми. 
2. Визначити структуру способу діяльності елементний склад і схему зв'язку між елементами.

3. Визначити ієрархічний статус елементів і послідовність їх презентування.

4. Визначити комплекс предметно-наукових знань у відношенні до кожного конкретного елемента способу діяльності.

5. Визначити склад комплексу допоміжних знань (НПЗ, IH3, КО3, МН3, МП3), які забезпечують засвоєння даного способу діяльності за елементами.

6. Визначити конкретну галузь наукового знання, що залучається як допоміжний компонент.

7. Конкретизувати елементи наукових знань 3 кожної наукової галузі, що залучаються як допоміжний компонент.

8. Визначити функціональні зв'язки і логічні відношення конкретизованих галузевих елементів наукових знань 3 елементами провідного компонента - конкретного способу діяльності.

9. Заповнити матрицю.

Узагальнена змістова структура заповненої матриці має такий вигляд:

\begin{tabular}{|c|c|c|c|c|c|c|}
\hline \multirow[t]{2}{*}{ TK } & ПК & $\mathrm{N}_{1}$ & $\mathrm{~N}_{2}$ & $\mathrm{~N}_{3}$ & & $\mathrm{~N}_{\mathrm{n}}$ \\
\hline & ПНЗ & ПЗ $\mathrm{H}_{1}$ & $\mathrm{nH}_{2}$ & $\Pi \mathrm{H}_{2,3}$ & & $\Pi \mathrm{H}_{\mathrm{n}}$ \\
\hline \multirow{5}{*}{ дз } & $\mathrm{H} \Pi 3$ & $\mathrm{H} \Pi 3_{1}$ & $\mathrm{H} \Pi 3_{1,2}$ & $\mathrm{H} 3_{2,3}$ & & $\mathrm{H} \Pi 3_{2,3}$ \\
\hline & $\mathrm{IH} 3$ & & & $\mathrm{IH}_{1}$ & & $\mathrm{IH}_{4}$ \\
\hline & KO3 & & $\mathrm{KO}_{1,3}$ & $\mathrm{KO}_{1,2,3}$ & & $\mathrm{KO}_{\mathrm{n}}$ \\
\hline & $\mathrm{MH} 3$ & & $\mathrm{MH}_{1,2,3}$ & $\mathrm{MH}_{1,2,3}$ & & $\mathrm{MH}_{1,3}$ \\
\hline & МПЗ & $\mathrm{M}_{1}$ & МПЗ & & & \\
\hline
\end{tabular}

В полі матриці (клітинах) зазначені мікроелементи змісту теоретичного компонента. Вони розташовані відповідно до основних елементів провідного компонента змісту фізкультурної освіти способи рухової діяльності.

Змістова структура отриманої матриці з доповненням допоміжних способів діяльності являе собою структурну модель змісту конкретної теми
- логічно завершеного фрагмента, змісту фізкультурної освіти.

Як приклад наведемо розроблені нами повно розгорнуті структурні моделі завершеного фрагмента змісту фізкультурної освіти для шостого класу загальноосвітньої школи. В моделі I наведено зміст освіти, обумовлений державною програмою (Комплексні програми середньої загальноосвітньої школи. Фізична культура.1-11 класи. - К.: Освіта, 1993), у моделі 2 наведено зміст, розроблений на основі процесуальної матриці.

\begin{tabular}{|c|c|c|c|c|}
\hline \multirow{2}{*}{ Тема } & \multirow{2}{*}{$\begin{array}{l}\text { Основний } \\
\text { блок } \\
\begin{array}{l}\text { Спосіб } \\
\text { діяльності }\end{array} \\
\end{array}$} & \multicolumn{3}{|c|}{ Процесуальний блок } \\
\hline & & $\begin{array}{l}\text { Предмет- } \\
\text { но-наукові } \\
\text { знання }\end{array}$ & $\begin{array}{l}\text { Допоміж- } \\
\text { ні знання }\end{array}$ & $\begin{array}{l}\text { Допоміжні } \\
\text { способи } \\
\text { діяльності }\end{array}$ \\
\hline $\begin{array}{l}\text { Спринтер- } \\
\text { ський біг } \\
(60 \text { м) }\end{array}$ & $\begin{array}{l}\text { Уміти: } \\
\text { виконува- } \\
\text { ти старто- } \\
\text { вий роз- } \\
\text { гін; } \\
\text { бігати з } \\
\text { максима- } \\
\text { льною } \\
\text { швидкіс- } \\
\text { тю на } \\
\text { відстань } \\
60 \text { м }\end{array}$ & Знати: & $\begin{array}{l}\text { Знати: } \\
\text { правила } \\
\text { безпеки } \\
\text { під час } \\
\text { виконан- } \\
\text { ня фізич- } \\
\text { них вправ } \\
\text { на май- } \\
\text { данчику }\end{array}$ & Уміти: \\
\hline
\end{tabular}

Порівняльний аналіз двох моделей показує, що використання процесуальної матриці сприяє збільшенню обсягу предметно-наукових знань, введенню комплексу допоміжних знань (нормативнопрофілактичних, історико-наукових, контрольнооціночних, міжнаукових, міжпредметних), дає можливість значно поширити кількість допоміжних способів діяльності, конкретизувати основні елементи способів діяльності з урахуванням теми заняття.

Наведений зміст не претендує на оптимальний об'єм і наукову безпомилковість. Пропонована модель $є$ тільки певним орієнтиром в доборі і конструюванні змісту певної теми програми. Використання зазначеної моделі вчителями шкіл

Модель 2

\begin{tabular}{|c|c|c|c|c|}
\hline \multirow{2}{*}{ Тема } & \multirow{2}{*}{ Основний блок } & \multicolumn{3}{|c|}{ Процесуальний блок (експериментальний варіант) } \\
\hline & & $\begin{array}{c}\text { Предметно-наукові } \\
\text { знання }\end{array}$ & Допоміжні знання & $\begin{array}{c}\text { Допоміжні способи } \\
\text { діяльності }\end{array}$ \\
\hline $\begin{array}{l}\text { Спринтерсь- } \\
\text { кий біг на } 60 \text { м }\end{array}$ & $\begin{array}{l}\text { Уміти: } \\
\text { займати стартове по- } \\
\text { ложення }\end{array}$ & \begin{tabular}{|l|} 
Знати: \\
варіанти низького \\
і високого старту; \\
загальнорозвиваючі \\
вправи бігуна; \\
спеціальні і підготовчі \\
вправи бігуна
\end{tabular} & \begin{tabular}{|l} 
Знати: \\
нормативно-профі- \\
лактичні \\
правила безпеки під \\
час виконання бігу на \\
60 м (достатній \\
розігрів основних \\
груп м'язів і зв'язок, \\
обов'язкове виконан- \\
ня спеціальних і \\
підготовчих вправ \\
бігуна, бігти тільки по
\end{tabular} & $\begin{array}{l}\text { Уміти: } \\
\text { приймати положення низь- } \\
\text { кого і високого старту; } \\
\text { вибігати } 3 \text { низького старту } \\
\text { у нахилі; }\end{array}$ \\
\hline
\end{tabular}


Продовження (модель 2)

\begin{tabular}{|c|c|c|c|c|}
\hline \multirow{2}{*}{ Тема } & \multirow{2}{*}{ Основний блок } & \multicolumn{3}{|c|}{ Процесуальний блок (експериментальний варіант) } \\
\hline & & $\begin{array}{c}\text { Предметно-наукові } \\
\text { знання }\end{array}$ & Допоміжні знання & $\begin{array}{c}\text { Допоміжні способи } \\
\text { діяльності }\end{array}$ \\
\hline & $\begin{array}{l}\text { виконувати стартовий } \\
\text { розгін }\end{array}$ & $\begin{array}{l}\text { правила вибігання } \\
\text { з низького старту }\end{array}$ & $\begin{array}{l}\text { окремій доріжці, не } \\
\text { перебігати на інші } \\
\text { доріжки, після фініш- } \\
\text { ної лінії різко не галь- } \\
\text { мувати; яку першу до- } \\
\text { помогу треба зробити } \\
\text { при травмах) }\end{array}$ & $\begin{array}{l}\text { виконувати загальнорозви- } \\
\text { ваючі вправи бігуна на } \\
\text { спринтерській дистанції; } \\
\text { виконувати дріботливий біг; } \\
\text { виконувати біг з високим } \\
\text { підніманням стегна; } \\
\text { виконувати біг стрибками }\end{array}$ \\
\hline & $\begin{array}{l}\text { бігти з максималь- } \\
\text { ною швидкістю на } \\
\text { відстань } 60 \text { м }\end{array}$ & $\begin{array}{l}\text { техніку бігу на дис- } \\
\text { танції; } \\
\text { правила дихання під } \\
\text { час бігу; } \\
\text { темп і ритм бігу; } \\
\text { вплив довжини кроків } \\
\text { і частоти ї виконан- } \\
\text { ня на швидкість бігу; } \\
\text { правила контролю і } \\
\text { самоконтролю за тех- } \\
\text { нікою бігу на } 60 \text { м }\end{array}$ & $\begin{array}{l}\text { контрольно-оціночні } \\
\text { склад основних компо- } \\
\text { нентів бігу на } 60 \text { м; } \\
\text { як визначити опти- } \\
\text { мальний темп і ритм } \\
\text { бігу на } 60 \text { м; } \\
\text { вплив довжини кроків } \\
\text { і частоти їх виконання } \\
\text { на швидкість бігу; } \\
\text { правила контролю } \\
\text { і самоконтролю за } \\
\text { технікою бігу на } 60 \text { м }\end{array}$ & $\begin{array}{l}\text { бігти по дистанції широким } \\
\text { кроком з додержанням оп- } \\
\text { тимального ритму; } \\
\text { тримати максимальний темп } \\
\text { протягом всієї дистанції; } \\
\text { контролювати темп і ритм бігу } \\
\text { під час подолання дистанції; } \\
\text { аналізувати стан здоров'я } \\
\text { під час бігу; } \\
\text { регулювати навантаження на } \\
\text { основні групи м'язів і зв'язок; } \\
\text { аналізувати ритм дихання під } \\
\text { час бігу на } 60 \text { м }\end{array}$ \\
\hline & активно фінішувати & $\begin{array}{l}\text { способи фінішування; } \\
\text { якими приладами ви- } \\
\text { мірюється результат } \\
\text { бігу на спринтерські } \\
\text { дистанції; } \\
\text { правила змагань } 3 \\
\text { бігу на } 60 \text { м }\end{array}$ & $\begin{array}{l}\text { міжнаукові } \\
\text { вплив бігу на основні } \\
\text { функціональні системи } \\
\text { організму; } \\
\text { вплив спринтерського } \\
\text { бігу на розвиток швид- } \\
\text { кісних і швидкісно-си- } \\
\text { лових якостей; } \\
\text { методи діагностики } \\
\text { стану здоров'я під час } \\
\text { бігу }\end{array}$ & $\begin{array}{l}\text { активно фінішувати за раху- } \\
\text { нок кидка на фінішну стрічку; } \\
\text { надати першу допомогу при } \\
\text { травмах } \\
\\
\end{array}$ \\
\hline & & & $\begin{array}{l}\text { міжпредметні } \\
\text { вплив законів фізики на } \\
\text { положення бігуна під } \\
\text { час старту і вибігання } \\
\text { з низького старту }\end{array}$ & \\
\hline
\end{tabular}

Харківської області дозволило оптимізувати процес планування.

Дослідження показали, що розроблена нами на основі загально-дидактичної моделі навчального предмета процесуальна матриця є достатньо інструментальною і ефективною основою добору і конструювання теоретичного компонента, змісту фізкультурної освіти в загальноосвітній школі.

\section{Література}

1. Давыдов В.В. Проблемы развивающего обучения. М.: Педагогика, 1986.

2. Журавлев В.И., Зорина Л.Я. Представления об учебном предмете // Теоретические основы содержания общего среднего образования / Под ред. В.В. Краевского, И.Я Лернера. - М.: Педагогика, 1983.

3. Журавлев В.И. Связь педагогики с другими отраслями научного знания // Сов. педагогика, 1990, № 4.

4. Зорина Л.Я. Программа-учебник-учитель. - М.: Знание, 1989.

5. Лернер И.Я. Базовое содержание общего среднего образования // Сов. педагогика, 1991, № 11.

6. Лозова В.І., Москаленко П.Г., Троцко Г.В. Педагогіка. Розділ «Дидактика». - К.: ІСДОУ, 1993.

7. Москаленко П.Г., Гадецький М.В. Основи теорії навчання. - Харків, 1992.

8. Теоретические основы содержания общего среднего образования // Под ред. В.В. Краевского, И.Я. Лернера. - М.: Педагогика, 1983. 